\title{
Jenis Proses Berpikir Peserta Didik dalam Menyelesaikan Soal Literasi Matematis
}

\author{
Lestariningsih ${ }^{1}$, Eni Nurhayati ${ }^{2}{\text { dan } \text { Cicinidia }^{3}}^{3}$ \\ 1*2,3Program Studi Pendidikan Matematika, STKIP PGRI Sidoarjo \\ Jalan Kemiri, Sidoarjo, Jawa Timur, Indonesia \\ 1*lestari.med@gmail.com, 2eninurhayati188@gmail.com,33cicinidia.ia210@gmail.com
}

Artikel diterima: 21-10-2019, direvisi: 29-01-2020, diterbitkan: 31-01-2020

\begin{abstract}
Abstrak
Penelitian ini bertujuan mendeskripsikan jenis proses berpikir peserta didik dalam menyelesaikan soal literasi matematis berdasarkan jenis kelamin. Penelitian ini dilaksanakan di kelas X. Subjek penelitian ini adalah 2 peserta didik terdiri dari 1 peserta didik laki-laki dan 1 peserta didik perempuan yang berusia 15 tahun. Penelitian dilakukan menggunakan metode deskriptif kualitatif. Instrumen yang digunakan adalah soal literasi matematis dan pedoman wawancara untuk mendukung kegiatan think aloud. Hasil penelitian menunjukkan bahwa jenis proses berpikir kedua subjek penelitian termasuk proses berpikir konseptual. Subjek penelitian menyatakan aspek dalam soal menggunakan bahasa mereka sendiri atau mengubah ke dalam bentuk kalimat matematika, menyatakan aspek yang ditanya di dalam soal menggunakan bahasa sendiri atau mengubah ke dalam kalimat matematika, menyusun rencana penyelesaian, menuliskan langkah dalam menyelesaikan soal, dan mampu memperbaiki kekeliruan jawaban. Dari hasil penelitian, diketahui bahwa tidak ditemukan perbedaan yang besar antara laki-laki dan perempuan dalam menyelesaikan soal literasi matematis.

Kata Kunci: laki-laki, literasi matematis, perempuan, proses berpikir.
\end{abstract}

\section{Types of Students' Thinking Processes in Solving Mathematical Literacy Questions}

\begin{abstract}
This study aims to describe the types of students' thought processes in solving mathematical literacy problems based on gender. This research was conducted in class $X$. The subjects of this study were 2 students consisting of 1 male student and 1 female student who was 15 years old. The study was conducted using descriptive qualitative methods. The instrument used was a matter of mathematical literacy and interview guidelines to support think-aloud activities. The results showed that the types of thought processes of the two research subjects included conceptual thinking processes. Research subjects stated aspects of the problem using their language or changing it into mathematical sentences, stated aspects that were asked in the problem using their language or changed it into mathematical sentences, compiled a plan of completion, wrote the steps in solving the problem, and were able to correct the wrong answers. From the results of the study, it was found that there were no significant differences between men and women in solving mathematical literacy problems.

Keywords: male, mathematical literacy, female, thought process.
\end{abstract}




\section{Pendahuluan}

Soal literasi matematis biasanya dinyatakan dalam bentuk masalah kontekstual atau soal yang menggunakan konteks dunia nyata (Maryati, 2018). Programme for International Student Assessment (PISA) adalah kajian internasional untuk mengevaluasi hasil belajar yang salah satu tujuannya menguji literasi matematis peserta didik usia 15 tahun (Rahmawati, Mardiyana, \& Usodo, 2015).

Muzaki dan Masjudin (2019) telah melakukan penelitian dalam menganalisis kemampuan literasi matematis siswa. Fatwa, Septian, dan Inayah (2019) telah menerapkan model pembelajaran Problem Based Instruction untuk meningkatkan kemampuan literasi matematis siswa. Sementara itu, Prabawati, Herman, dan Turmudi mengembangkan lembar kerja siswa berbasis masalah dengan strategi heuristic untuk meningkatkan kemampuan literasi matematis siswa.

Berdasarkan hasil survei PISA tahun 2015, peserta didik Indonesia menunjukkan peningkatan hasil kinerja dalam kompetensi matematika sebesar 11 poin dari 375 poin di tahun 2012 menjadi 386 poin di tahun 2015. Pada PISA 2012, Indonesia berada diperingkat ke-64 dari 65 negara. Sedangkan pada PISA 2015, Indonesia berada diperingkat ke-64 dari 72 negara (Pressreader, 2016). Berdasarkan data tersebut, terlihat jelas bahwa kemampuan peserta didik Indonesia yang berusia 15 tahun secara umum masih sangat rendah (Rinaldi \& Afriansyah, 2019) khususnya dalam bidang literasi matematis. Oleh karena itu, perlu upaya untuk mengubah proses pembelajaran matematika di Indonesia, terutama yang dilakukan guru untuk menghadapi kesulitan peserta didik (Afriansyah, 2015) dalam menyelesaikan soal matematika.

Salah satu upaya guru adalah dengan melihat proses berpikir peserta didik dalam menyelesaikan masalah matematika (Pitriani \& Afriansyah, 2017). Hal tersebut sangat diperlukan karena dengan kemampuan berpikir yang baik, maka peserta didik dapat lebih mudah dalam memahami konsep matematika yang sedang dipelajarinya. Selain itu, proses berfikir antara siswa satu dengan siswa yang lain tidak selalu sama (Yanti \& Syazali, 2016).

Proses berfikir dibedakan menjadi tiga, yaitu konseptual, semi konseptual, dan komputasional (Zuhri, 1998). Proses berpikir konseptual merupakan proses berpikir dalam menyelesaikan tugas dengan menggunakan konsep yang telah dimiliki. Proses berpikir semi konseptual adalah proses berfikir dalam menyelesaikan tugas dengan menggunakan konsep yang dimiliki dan dipadukan dengan intuisi. Proses berfikir komputasional adalah proses berpikir dalam menyelesaikan tugas tanpa menggunakan konsep tetapi mengandalkan intuisi.

Berdasarkan uraian tersebut, diperlukan adanya kajian lebih mendalam 
lagi tentang jenis proses berpikir peserta didik (Mulyo, Sari, \& Syarifuddin, 2019) dalam menyelesaikan soal literasi matematis. Soal literasi matematis yang diukur adalah soal literasi matematis level 3, dikarenakan sebagian peserta didik Indonesia telah dapat menyelesaikan atau menempati literasi matematis pada level 3 pada studi PISA.

Hasil penelitian nasional yang dilakukan oleh Departemen Pendidikan Amerika Serikat menunjukkan bahwa anak dengan jenis kelamin laki-laki sedikit lebih baik dibandingkan anak dengan jenis kelamin perempuan dalam pelajaran matematika dan sains. Walaupun demikian, secara rata-rata anak perempuan merupakan pelajar yang lebih baik dan mereka secara signifikan lebih baik dari anak laki-laki dalam membaca (Santrock, 2007). Perbedaan kemampuan yang dimiliki anak laki-laki dan anak perempuan tersebut bisa menjadi penyebab munculnya perbedaan proses berpikir antara anak laki-laki dan anak perempuan dalam menyelesaikan soal literasi matematis. Berdasarkan kenyataan ini, penelitian ini bertujuan mendeskripsikan jenis proses berpikir peserta didik laki-laki dan perempuan dalam menyelesaikan soal literasi matematis.

\section{Metode}

Penelitian ini menggunakan metode deskriptif kualitatif karena data yang diperoleh berupa data kualitatif yang mendeskripsikan secara jelas tentang jenis proses berpikir peserta didik laki-laki dan perempuan dalam menyelesaikan soal literasi matematis beserta alasan dan data pendukungnya. Penelitian ini dilakukan di kelas X MIPA 4 SMA Muhammadiyah 3 Tulangan dengan subjek berjumlah 2 peserta didik yang berusia 15 tahun yang terdiri dari satu peserta didik laki-laki dan satu peserta didik perempuan. Subjek penelitian laki-laki dan perempuan diambil dari siswa yang memiliki kemampuan matematika yang relatif sama berdasarkan nilai penilaian akhir semester siswa.

Instrumen yang digunakan pada penelitian ini adalah satu soal literasi matematis dengan mengadaptasi soal dari Programme for International Student Assessment (PISA) dan pedoman wawancara untuk mendukung keabsahan data. Teknik menguji keabsahan data menggunakan triangulasi metode, yaitu dengan membandingkan data pekerjaan siswa dan data think aloud. Sebelum soal literasi matematis digunakan, peneliti terlebih dahulu melakukan validasi ahli kepada dua orang dosen Pendidikan matematika dan satu guru matematika. Validasi dilakukan dengan menggunakan lembar validasi dan diperoleh hasil bahwa instrumen tersebut valid dari aspek konten dan bahasa.

Teknik pengumpulan data pada penelitian ini menggunakan tugas soal literasi matematis dan metode think aloud. Think aloud adalah suatu metode dalam mengumpulkan data dari subjek penelitian dengan cara subjek penelitian 
menverbalkan atau mengatakan tentang aspek yang dipikirkan, dirasakan, dan pendapat tentang aspek yang dilakukannya yang dilaksanakan bersamaan dengan saat menyelesaikan tugas atau proses evaluasi. Metode think aloud ini dapat digunakan untuk mendapatkan data mengenai proses berpikir individu. Metode think aloud pada penelitian ini menggunakan teknik introspeksi (introspection). Menurut Djiwandono (2015), introspeksi yaitu responden melaporkan proses berpikirnya ketika sedang mengerjakan sesuatu.

Data hasil tes literasi matematis dengan think aloud dianalisis berdasarkan indikator-indikator yang memenuhi jenis proses berpikir konseptual, semi konseptual, dan komputasional. Indikator jenis proses berfikir yang digunakan dalam penelitian ini disajikan dalam Tabel 1 dengan mengadaptasi indikator proses berfikir yang dikemukakan oleh Zuhri (1998) dan Wing (2011).

Aturan yang digunakan untuk mendeskripsikan jenis proses berpikir peserta didik mengacu pada pendapat Nugroho (2013) yaitu:

1. Subjek dikatakan memiliki jenis proses berpikir tertentu jika indikatorindikator jenis proses berpikir tersebut lebih banyak terpenuhi daripada yang lainnya.

2. Jika subjek tidak memenuhi kriteria 1 , maka jenis proses berpikir subjek tidak dapat diklasifikasikan.

Tabel 1.

Indikator Jenis Proses Berpikir

\begin{tabular}{ccc}
\hline Jenis Proses Berpikir Konseptual & $\begin{array}{c}\text { Jenis Proses Berpikir Semi } \\
\text { Konseptual }\end{array}$ & $\begin{array}{c}\text { Jenis Proses Berpikir } \\
\text { Komputasional }\end{array}$
\end{tabular}

1. Mampu menyatakan aspek yang diketahui dalam soal dengan bahasa sendiri atau mengubah dalam kalimat matematika (K1.1)

2. Mampu menyatakan aspek yang ditanya dalam soal dengan bahasa sendiri atau mengubah dalam kalimat matematika (K1.2)

3. Membuat rencana penyelesaian dengan lengkap (K1.3)

4. Mampu menyatakan langkah-langkah yang ditempuh dalam menyelesaikan soal menggunakan konsep yang pernah dipelajari (K1.4)

5. Mampu memperbaiki kekeliruan jawaban (K1.5)
1. Kurang mampu menyatakan aspek yang diketahui dalam soal dengan bahasa sendiri atau mengubah dalam kalimat matematika (K2.1)

2. Kurang mampu menyatakan aspek yang ditanya dalam soal dengan bahasa sendiri atau mengubah dalam kalimat matematika (K2.2)

3. Membuat rencana penyelesaian tetapi tidak lengkap (K2.3)

4. Kurang mampu menyatakan langkah-langkah yang ditempuh dalam menyelesaikan soal menggunakan konsep yang pernah dipelajari (K2.4)

5. Kurang mampu memperbaiki kekeliruan jawaban (K2.5)
1. Tidak mampu menyatakan aspek yang diketahui dalam soal dengan bahasa sendiri atau mengubah dalam kalimat matematika (K3.1)

2. Tidak mampu menyatakan aspek yang ditanya dalam soal dengan bahasa sendiri atau mengubah dalam kalimat matematika (K3.2)

3. Tidak membuat rencana penyelesaian (K3.3)

4. Tidak mampu menyatakan langkah-langkah yang ditempuh dalam menyelesaikan soal menggunakan konsep yang pernah dipelajari (K3.4)

5. Tidak mampu memperbaiki kekeliruan jawaban (K3.5) 


\section{Hasil dan Pembahasan}

Instrumen tugas literasi matematis dengan prediksi level 3 yang digunakan dalam penelitian ini menggunakan konten bentuk dan ruang, dan konteks ilmiah. Berikut tugas literasi matematis tersebut.

Sebuah pintu putar (revolving door) terdiri dari tiga sayap yang berputar dalam bentuk lingkaran (Gambar 2). Diameter bagian dalam dari ruang tersebut adalah 2 meter (200 centimeter). Ketiga sayap pintu itu membagi ruang ke dalam tiga bidang yang sama. Gambar 1 menunjukkan sayap pintu dalam tiga posisi yang berbeda apabila dilihat dari atas. Berapakah luas daerah yang dibentuk oleh dua sayap pintu yang berdekatan?

Indikator jenis proses berpikir peserta didik pada bagian 1 adalah mampu menyatakan aspek yang diketahui dalam soal menggunakan bahasa sendiri atau mengubahnya ke dalam kalimat matematika (K1.1), kurang mampu menyatakan aspek yang diketahui dalam soal dengan bahasa sendiri atau mengubah ke dalam kalimat matematika (K2.1), dan tidak mampu menyatakan aspek yang diketahui di dalam soal menggunakan bahasa sendiri atau mengubahnya dalam kalimat matematika

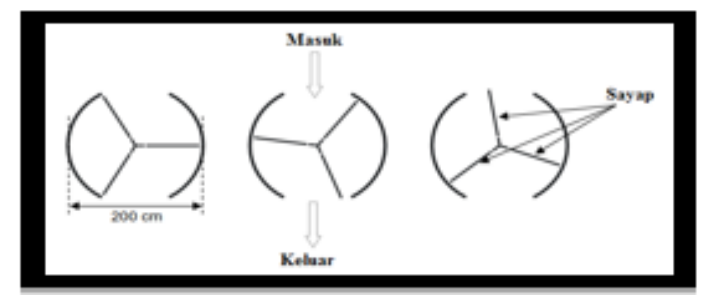

Gambar 1. Sayap Pintu dalam Tiga Posisi.
(K3.1). Paparan hasil tes literasi matematis dengan think aloud sebagai berikut.

Pada Gambar 2, terlihat bahwa subjek laki-laki menuliskan dengan lengkap dan benar apa yang diketahui dalam soal dengan bahasa sendiri. Subjek Laki-Laki (SL) juga mengungkapkan dengan lengkap dan benar aspek yang diketahui dalam soal dengan bahasa sendiri, hal ini dapat dilihat dari kutipan think aloud sebagai berikut:

Peneliti (P): "Apa yang diketahui dari soal?"

SL: "Diketahui diameternya 200 cm."

P: "Ada lagi yang diketahui?"

SL: "Tidak ada."

Berdasarkan hasil paparan tes literasi matematis dengan think aloud dapat dikatakan bahwa subjek laki-laki mencapai indikator K1.1.

Pada Gambar 3, terlihat bahwa subjek perempuan menuliskan dengan lengkap dan benar aspek yang diketahui dalam soal dengan bahasa sendiri. Subjek perempuan (SP) juga mengungkapkan dengan lengkap dan benar aspek yang diketahui dalam soal dengan bahasa sendiri, hal ini dapat dilihat dari kutipan think aloud berikut:

P : “Apa yang diketahui dari soal?"

SP : "Diketahui lingkaran dengan diameter 2 meter atau 200 centimeter."

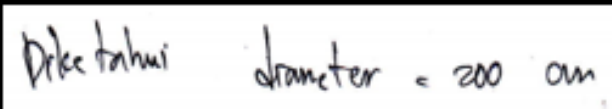

Gambar 2. Hasil Tes Literasi Matematis Subjek Laki-laki Bagian 1.

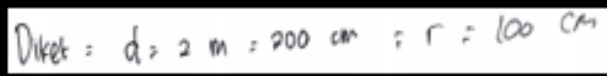

Gambar 3. Hasil Tes Literasi Matematis Subjek Perempuan Bagian 1.

\section{Mosharafa: Jurnal Pendidikan Matematika}


Berdasarkan hasil paparan tes literasi matematis dengan think aloud dapat dikatakan bahwa subjek perempuan mencapai indikator K1.1.

Indikator jenis proses berpikir peserta didik pada bagian 2 adalah mampu menyatakan aspek yang ditanya dalam soal dengan bahasa sendiri atau mengubah dalam kalimat matematika (K1.2), kurang mampu menyatakan aspek yang ditanya dalam soal dengan bahasa sendiri atau mengubah dalam kalimat matematika (K2.2), dan tidak mampu menyatakan aspek yang ditanya dalam soal dengan bahasa sendiri atau mengubah dalam kalimat matematika (K3.2). Paspekran hasil tes literasi matematis dengan think aloud sebagai berikut.

Pada Gambar 4, terlihat bahwa subjek laki-laki menuliskan dengan lengkap dan benar aspek yang ditanya dalam soal dengan bahasa sendiri. Subjek laki-laki juga mengungkapkan dengan lengkap dan benar aspek yang ditanya dalam soal dengan bahasa sendiri, hal ini dapat dilihat dari kutipan think aloud sebagai berikut:

$P$ : "Apa yang ditanya dari soal?" SL : "Yang ditanya mencari luas daerah yang dibentuk oleh

dua sayap pintu yang berdekatan."

P : "Luas daerah yang dibentuk oleh dua sayap pintu yang

berdekatan, yang mana?

SL : "Yang ini." (sambil menunjuk 2 sayap pintu yang

berdekatan pada Gambar 1)

P : "Berarti mencari daerah yang mana?"
SL : "Ini, sepertiganya." (sambil menunjuk daerah yang akan dicari pada Gambar 1)

Berdasarkan hasil paparan tes literasi matematis dengan think aloud dapat dikatakan bahwa subjek laki-laki mencapai indikator K1.2.

Pada Gambar 5, terlihat bahwa subjek perempuan menuliskan dengan lengkap dan benar aspek yang ditanya dalam soal dengan bahasa sendiri. Subjek perempuan juga mengungkapkan dengan lengkap dan benar aspek yang ditanya dalam soal dengan bahasa sendiri, hal ini dapat dilihat dari kutipan think aloud sebagai berikut:

P: “Apa yang ditanya dari soal?"

SP : "Ditanya luas daerah yang dibentuk oleh dua sayap."

$P$ : "Oleh dua sayap pintu, mana sih yang ditanya nanti?"

SP : "Ini." (sambil menunjuk $\frac{1}{3}$ bagian lingkaran pada Gambar 1)

P : "Sayapnya mana?"

SP : "Ini." (sambil menunjuk dua sayap pintu yang berdekatan)

Berdasarkan hasil paparan tes literasi matematis dengan think aloud dapat dikatakan bahwa subjek perempuan mencapai indikator K1.2.

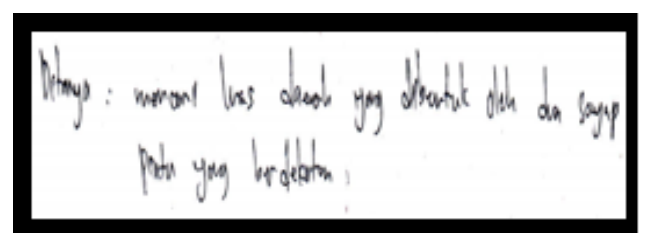

Gambar 4. Hasil Tes Literasi Matematis Subjek Laki-laki Bagian 2.

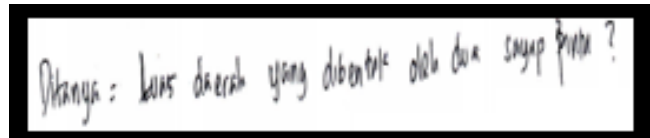

Gambar 5. Hasil Tes Literasi Matematis Subjek Perempuan Bagian 2. 
Indikator jenis proses berpikir peserta didik pada bagian 3 adalah membuat rencana penyelesaian dengan lengkap (K1.3), membuat rencana penyelesaian tetapi tidak lengkap (K2.3), dan tidak membuat rencana penyelesaian (K3.3). Paparan hasil tes literasi matematis dengan think aloud sebagai berikut.

Pada Gambar 6, terlihat bahwa subjek laki-laki menuliskan rencana penyelesaian dengan lengkap dan benar. Subjek laki-laki juga mengungkapkan rencana penyelesaian dengan lengkap dan benar, hal ini dapat dilihat dari kutipan think aloud sebagai berikut:

P : "Apa rencana yang digunakan untuk menyelesaikan soal?"

SL : "Rencana penyelesaiannya mencari jarijarinya dulu, kan luas lingkaran. Jadi sepertiga lingkarannya dari luasnya."
P : :Terus diapakan?"
SL : "Dicari hasilnya."

Berdasarkan hasil paparan tes literasi matematis dengan think aloud dapat dikatakan bahwa subjek laki-laki mencapai indikator K1.3.

Pada Gambar 7, terlihat bahwa subjek

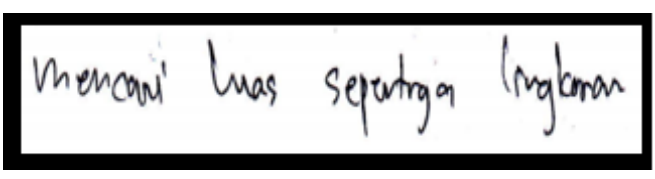

Gambar 6. Hasil Tes Literasi Matematis Subjek Laki-laki Bagian 3.

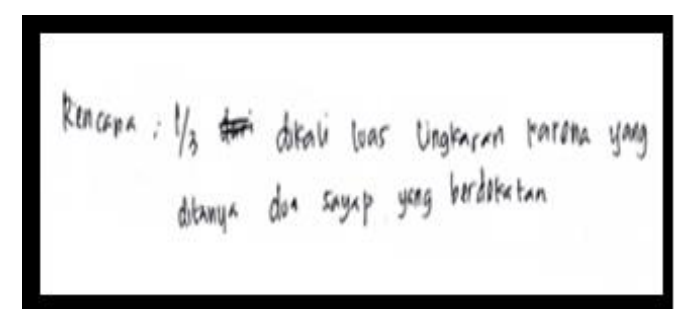

Gambar 7. Hasil Tes Literasi Matematis Subjek Perempuan Bagian 3. perempuan menuliskan rencana penyelesaian dengan lengkap dan benar. Subjek perempuan juga mengungkapkan rencana penyelesaian dengan lengkap dan benar, hal ini dapat dilihat dari kutipan think aloud sebagai berikut:

P : "Apa rencana yang digunakan untuk menyelesaikan soal?"

SP : "Rencana, ini kan dibagi 3 , jadi $\frac{1}{3}$ dari luas lingkaran." (sambil menunjuk lingkaran pada Gambar 1)

P : "Mengapa dibagi 3?"

SP : "Sayapnya kan 3, lingkarannya 1, yang ditanya cuma 2 sayap yang berdampingan itu tadi. $\frac{1}{3}$ dikali dengan luas lingkaran karena yang ditanya adalah dua sayap pintu yang berdekatan."

Berdasarkan hasil paparan tes literasi matematis dengan think aloud dapat dikatakan bahwa subjek perempuan mencapai indikator K1.3.

Indikator jenis proses berpikir peserta didik pada bagian 4 adalah mampu menyatakan langkah-langkah yang ditempuh dalam menyelesaikan soal menggunakan konsep yang pernah dipelajari (K1.4), kurang mampu menyatakan langkah-langkah yang ditempuh dalam menyelesaikan soal menggunakan konsep yang pernah dipelajari (K2.4), dan tidak mampu menyatakan langkah-langkah yang ditempuh dalam menyelesaikan soal menggunakan konsep yang pernah dipelajari (K3.4). Paparan hasil tes literasi matematis dengan think aloud (lihat gambar 8).

Pada Gambar 8, terlihat bahwa subjek laki-laki menuliskan langkah-langkah

\section{Mosharafa: Jurnal Pendidikan Matematika}


penyelesaian dengan benar dalam menyelesaikan soal menggunakan konsep yang pernah dipelajari. Subjek laki-laki juga mengungkapkan langkah-langkah penyelesaian dengan benar dalam menyelesaikan soal menggunakan konsep yang pernah dipelajari, hal ini dapat dilihat dari kutipan think aloud sebagai berikut:

$\mathrm{P}$ : "Bagaimana langkah-langkah yang dilakukan dalam menyelesaikan soal?"

SL : : "Jadi rumusnya $\frac{1}{3} \pi r^{2}$."

P : : “ $\frac{1}{3}$ nya dari mana?”

SL : "Dari sini, kan ini dibagi tiga, jadi sepertiganya." (sambil

menunjuk lingkaran pada Gambar 1)

P : : " $\pi r^{2}$ nya itu apa?"

SL : "Ya rumusnya, rumus luas lingkaran kan $\pi r^{2} . \pi$ nya

dibuat 3,14. Sama jari-jarinya diambil dari, kan diameternya 200. Jari-jari itu setengah dari diameter jadi 100. Hasilnya 14,66."

P : : "Sebelumnya pernah gak belajar tentang rumus-rumus seperti ini di SMP, SMA, atau SD?

IDH : "Sudah, SD kelas 4. Jadi luas daerah yang dibentuk oleh dua sayap pintu yang berdekatan adalah 14,66 sentimeter persegi."

P : : "Kenapa menggunakan persegi?"

IDH : "Kan luas."

Berdasarkan hasil paparan tes literasi matematis dengan think aloud dapat dikatakan bahwa subjek laki-laki mencapai indikator K1.4.

Pada Gambar 9, terlihat bahwa subjek perempuan menuliskan langkah-langkah penyelesaian dengan benar dalam menyelesaikan soal menggunakan konsep yang pernah dipelajari. Subjek perempuan juga mengungkapkan langkah-langkah penyelesaian dengan benar dalam menyelesaikan soal menggunakan konsep yang pernah dipelajari, hal ini dapat dilihat dari kutipan think aloud sebagai berikut:

P : "Bagaimana langkah-langkah yang dilakukan dalam menyelesaikan soal?"

SP : "Penyelesaiannya $\frac{1}{3}$ dikali luas lingkaran, $\frac{1}{3}$ dikali $\frac{1}{2} \pi r^{2}, d$ nya tadi kan $200 \mathrm{~cm}$ jadi $r$ nya sama dengan $100 \mathrm{~cm}$, karena dibagi 2, $\frac{1}{3}$ dikali $\frac{1}{2}$ dikali $\frac{22}{7}$ dikali $100^{2}, \frac{22}{47}$ dikali $1000, \frac{22000}{47}$ sama dengan $523,34 \mathrm{~cm}^{2}$. Jadi luas daerah yang dibentuk oleh dua sayap pintu yang berdekatan adalah 523,34 $\mathrm{cm}^{2}$."

$\mathrm{P}:$ :Sudah yakin?"

SP : (senyum)

$\mathrm{P}$ : "Yakin apa gak?"

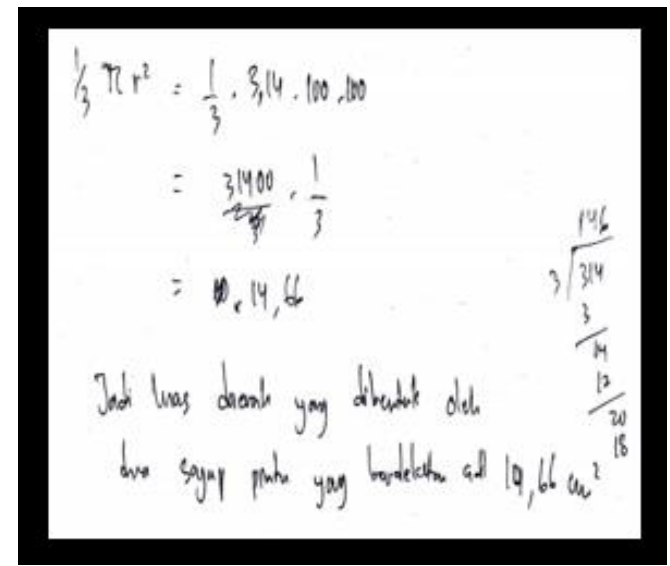

Gambar 8. Hasil Tes Literasi Matematis Subjek Laki-laki Bagian 4.

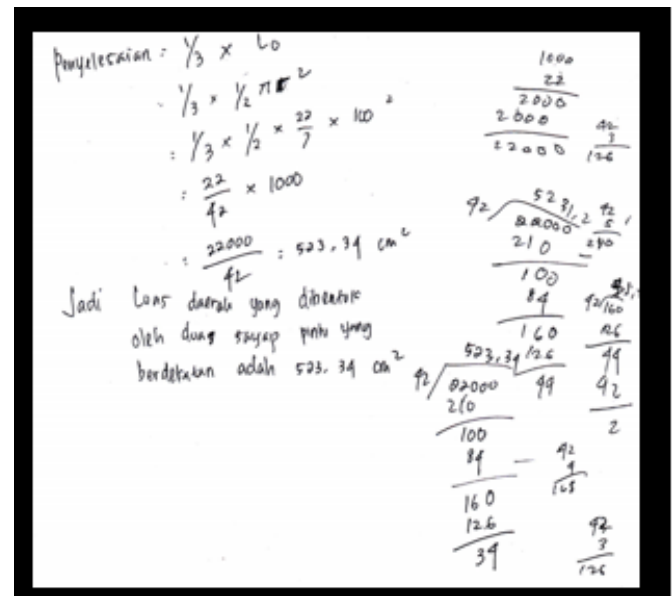

Gambar 9. Hasil Tes Literasi Matematis Subjek Perempuan Bagian 4. 
SP : "Yakin." (sambil menunjukkan ekspresi ragu-

ragu)

P : "Ragu-ragu gitu, gak yakinnya dimana?"

SP : "Ini loh rumus lingkaran."

P : "Kenapa? gak hafal?"

SP : "Nggak."

$P$ : "Waktu kapan diajarin?"

SP : "SMP."

P : "Jadi problem nya disini." (sambil menunjuk rumus luas lingkaran pada lembar jawaban subjek penelitian)

SP : "Luas lingkaran."

Berdasarkan hasil paparan tes literasi matematis dengan think aloud dapat dikatakan bahwa subjek perempuan mencapai indikator K1.4.

Indikator jenis proses berpikir peserta didik pada bagian 5 adalah mampu memperbaiki kekeliruan jawaban (K1.5), kurang mampu memperbaiki kekeliruan jawaban (K2.5), dan tidak mampu memperbaiki kekeliruan jawaban (K3.5). Dari hasil tes literasi matematis dengan think aloud subjek laki-laki dan subjek perempuan tidak memeriksa kembali jawaban dan tidak memperbaiki jawaban jika terjadi kesalahan dalam proses penyelesaian soal. Hal tersebut menunjukkan bahwa subjek laki-laki dan subjek perempuan mencapai indikator K3.5.

Berdasarkan hasil tes literasi matematis dengan think aloud, dapat dikatakan bahwa jenis proses berpikir subjek laki-laki dan subjek perempuan merupakan jenis proses berpikir konseptual. Hal tersebut bertentangan dengan hasil penelitian yang dilakukan oleh Karim (2015) bahwa dalam memecahkan masalah matematika siswa laki-laki cenderung jenis proses berpikirnya semi konseptual, sedangkan siswa perempuan lebih cenderung jenis proses berpikirnya konseptual.

\section{Penutup}

Jenis proses berpikir peserta didik lakilaki dan peserta didik perempuan termasuk dalam kategori proses berpikir konseptual. Dalam menyelesaikan soal literasi matematis, kedua subjek penelitian mampu menyatakan aspek yang diketahui dalam soal dengan menggunakan bahasa sendiri, mampu mengubah aspek yang diketahui dalam kalimat matematika. Kemudian mereka mampu menyatakan aspek yang ditanyakan dalam soal dengan bahasa sendiri atau mengubah dalam kalimat matematis, membuat rencana penyelesaian dengan lengkap, mampu menyatakan langkah-langkah yang ditempuh dalam menyelesaikan soal menggunakan konsep yang pernah dipelajari, dan mampu memperbaiki kekeliruan jawaban.

Keterbatasan dalam penelitian ini adalah hasil penelitian yang diperoleh tidak dapat melihat indikator dari tahap memperbaiki kekeliruan jawaban atau indikator jenis proses berpikir peserta didik pada bagian 5 .

Selanjutnya, hasil penelitian dapat menjadi bahan pertimbangan bagi guru matematika dalam menyusun atau mendesain pembelajaran matematika khususnya yang terkait konten dalam literasi matematis. 


\section{UCAPAN TERIMA KASIH}

Penulis menyampaikan terima kasih kepada Direktorat Riset dan Pengabdian Masyarakat (DRPM) Kementerian Riset, Teknologi, dan Pendidikan Tinggi (Ristekdikti) melalui LLDIKTI Wilayah 7 karena telah mendanai penelitian ini melalui hibah Penelitian Dosen Pemula (PDP).

\section{Daftar Pustaka}

Afriansyah, E. A. (2015). Students' Misconception in Decimal Numbers. International Seminar on Teacher Education 1st ISTE UIN Suska Riau.

Djiwandono, P. I. (2015). Meneliti itu Tidak Sulit: Metodologi Penelitian Sosial dan Pendidikan Bahasa. Yogyakarta: Deepublish.

Fatwa, V. C., Septian, A., \& Inayah, S. (2019). Kemampuan Literasi Matematis Siswa melalui Model Pembelajaran Problem Based Instruction. Mosharafa: Jurnal Pendidikan Matematika, 8(3), 389398.

DOI: https://doi.org/10.31980/moshar afa.v8i3.535

Karim, A. (2015). Proses Berpikir Siswa Kelas VII SMP dalam Memecahkan Masalah Matematika Ditinjau dari Perbedaan Gender. Skripsi Tidak Diterbitkan. Sidoarjo: Program Studi Pendidikan Matematika STKIP PGRI Sidoarjo.
Maryati, I. (2018). Penerapan Model Pembelajaran Berbasis Masalah pada Materi Pola Bilangan di Kelas VII Sekolah Menengah Pertama. Mosharafa: Jurnal Pendidikan Matematika, 7(1), 63-74. DOI: https://doi.org/10.31980/moshar afa.v7i1.342

Mulyo, M. R. G. T., Sari, A. F., \& Syarifuddin, A. (2019). Proses Berpikir Siswa Bergaya Kognitif Visualizer dalam Menyelesaikan Masalah TIMSS Non Geometri. Mosharafa: Jurnal Pendidikan Matematika, 8(1), 167178.

DOI: https://doi.org/10.31980/moshar afa.v8i1.435

Muzaki, A., \& Masjudin. (2019). Analisis Kemampuan Literasi Matematis Siswa. Mosharafa: Jurnal Pendidikan Matematika, 8(3), 493-502. DOI: https://doi.org/10.31980/moshar afa.v8i3.557

Nugroho, R. A. (2013). Proses Berpikir Peserta didik dengan Kecerdasan Linguistik dan Logis Matematis dalam Memecahkan Masalah Matematika. MATHEdunesa, 3(2).

Pitriani, R., \& Afriansyah, E. A. (2017). Persepsi dalam Pembelajaran Pendekatan Keterampilan Proses terhadap Kemampuan Koneksi Matematis Siswa. Jurnal Gantang, 1(2), 15-24.

Prabawati, M. P., Herman, T., \& Turmudi. (2019). Pengembangan Lembar Kerja Siswa Berbasis Masalah dengan 
Strategi Heuristic untuk Meningkatkan

Kemampuan Literasi Matematis.

Mosharafa: Jurnal Pendidikan

Matematika, 8(1), 37-48.

DOI: https://doi.org/10.31980/moshar afa.v8i1.383

Pressreader. (2016). Indonesia. (Online).

\section{Tersedia:}

https://www.pressreader.com/indone sia/kompas/20161207/281848643226 223. Diakses pada tanggal 23 Januari 2018 pukul 24.20 WIB.

Rahmawati, N. D., Mardiyana, \& Usodo, B. (2015). Profil Peserta didik SMP dalam Pemecahan Masalah yang Berkaitan dengan Literasi Matematis Ditinjau dari Adversity Quotient (AQ). Jurnal Pembelajaran Matematika, 3(5).

Rinaldi, E., \& Afriansyah, E. A. (2019). Perbandingan

Kemampuan

Pemecahan Masalah Matematis Siswa antara Problem Centered Learning dan Problem Based Learning. NUMERICAL: Jurnal Matematika dan Pendidikan Matematika, 9-18.

Santrock. (2007). Perkembangan Anak. Edisi Kesebelas. Jakarta: Erlangga.

Wing, J. (2011). Research notebook: Computational thinking-What and why. The Link Magazine, 20-23.

Yanti, A., \& Syazali, M. (2016). Analisis Proses Berpikir Siswa dalam Memecahkan Masalah Matematika berdasarkan Langkah-Langkah Bransford dan Stein ditinjau dari Adversity Quotient. Al-Jabar : Jurnal Pendidikan Matematika, 7(1), 63-74. doi:https://doi.org/10.24042/ajpm.v7i 1.132

Zuhri, D. (1998). Proses Berpikir Peserta didik Kelas II SMP Negeri 16 Pekanbaru dalam Menyelesaikan SoalSoal Perbandingan Senilai dan Perbandingan Berbalik Nilai. Thesis Tidak Dipublikasikan. Surabaya: UNESA.

\section{Riwayat Hidup PENUlis}

Lestariningsih, M.Pd.

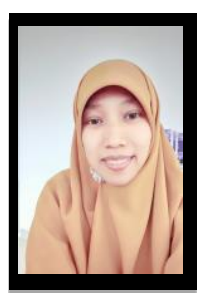

Lahir di Jombang, 6 Juni 1985. Staf pengajar di STKIP PGRI Sidoarjo. Studi S1 Pendidikan Matematika, Universitas Negeri Surabaya, Surabaya, lulus tahun 2008; S2 Pendidikan Matematika, Universitas Sriwijaya, Palembang, lulus tahun 2012.

\section{Eni Nurhayati, M.Pd.}

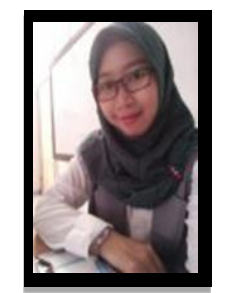

Lahir di Surabaya, 23 Juli 1988. Staf pengajar di STKIP PGRI Sidoarjo. Studi S1 Pendidikan Bahasa dan Sastra Indonesia, Universitas Negeri Surabaya, Surabaya, lulus tahun 2011; S2 Pendidikan Bahasa dan Sastra Indonesia (Universitas negeri Surabaya, Surabaya, lulus tahun 2015.

\section{Cicinidia, S.Pd.}

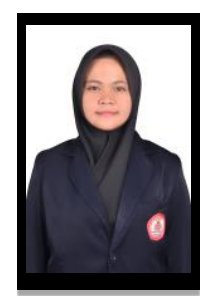

Lahir di Pasuruan, 7 Februari 1996. Staf pengajar di SMA muhammadiyah 3 Tulangan. Studi S1 Pendidikan Matematika, STKIP PGRI Sidoarjo, lulus tahun 2018. 
http://journal.institutpendidikan.ac.id/index.php/mosharafa

This page is intentionally left blank 